\title{
Performance Evaluation of MGNREGS in Himachal Pradesh
}

\author{
Dr. Tek Chand \\ Assistant Professor, Dept. of Commerce, SLC Eve., University of Delhi. \\ DOI: 10.29322/IJSRP.11.11.2021.p11904 \\ http://dx.doi.org/10.29322/IJSRP.11.11.2021.p11904
}

\begin{abstract}
MGNREGS is one of the schemes, which has attained considerable recognition among rural masses. It plays an important role in the upliftment of rural people. In this paper, an attempt has been made to evaluate the Performance of MGNREGS in Himachal Pradesh from 2015-20 in the last five years in terms of employment demanded by rural households and employment offered by Panchayati Raj Institution representatives, and hundred days assured work completed by beneficiaries. In addition, financial performance i.e. growth of fund utilization in the programme is also taken into consideration in the study. For accomplishing the objectives of the study, secondary data was collected and analyzed with help of statistical tools Mean and CAGR. The outcome of the study is summarized that growth has been found at every phase of the programme and it is playing a significant role in the socio-economic development of rural masses.
\end{abstract}

Index Terms- MGNREGS, Performance, and Employment

\section{INTRODUCTION}

$\mathrm{M}$ ahatma Gandhi Employment Guarantee Act 2005, is an Indian labour law and social security measure that aims to guarantee the 'Right to Work'. This act was passed on 23 August 2005 under the UPA government of Prime Minister Dr. Manmohan Singh. The NREGS came into force, on a pilot basis, on February 2, 2006 and was implemented in a phased manner. In first phase, it was introduced in 200 of the most economically backward districts of the country. In 2007, the second phase of implementation, it was extended to 130 additional districts and the remaining districts were covered in the third phase on April 1, 2008. The law was initially called the National Rural Employment Guarantee Act (NREGA) and was renamed with the prefix "Mahatma Gandhi" on 2 October 2009, Gandhi's birth anniversary.

The objective of MGNREGA is to ensure the livelihood security of rural people by guaranteeing at least 100 days of wage employment in a financial year to every household whose adult members volunteer to do unskilled manual work. Another aim of MGNREGA is to create durable assets (such as Pedestrians, Roads, Agri-Land, Canals, Ponds, and Wells etc). Employment is to be provided within $5 \mathrm{~km}$ of an applicant's residence, and minimum wages are to be paid. If work is not provided within 15 days of applying, applicants are entitled to an unemployment allowance. Therefore, employment under MGNREGA is a legal right.

This publication is licensed under Creative Commons Attribution CC BY.

http://dx.doi.org/10.29322/IJSRP.11.11.2021.p11904

\section{MGNREGA in Himachal Pradesh}

As per details from Census 2011, around 89.97 per cent of people of Himachal Pradesh lives in villages of rural areas, which is extremely backward. So, it is recognized as one of the backward states of the country. Therefore, the GOI implemented the MGNREGA in the state in a phased manner, keeping in notice the rural population and economic status of the people. In the first phase, it was introduced in two districts i.e. Chamba and Sirmour. During the second phase, two more districts were included namely Kangra and Mandi, and the remaining eight districts (Solan, Shimla, Bilaspur, Hamirpur, Kinnaur, Lahoul-Spiti, Una and Kullu) were covered in the third phase. At present, the MGNREGS is operating in all twelve districts of the state covering 78 blocks and 3326 Gram Panchayats. Since the inception of this scheme and to till the end of the year 2019-20, total number of 12.67 Lakhs households have been issued job cards.

\section{LITERATURE REVIEW}

Rengasamy and Kumar (2011) in their article, "State Level Performance of MGNREGA in India: A Comparative Study", have cleared that MGNREGA has immense potential to provide social security to rural masses, if its implementation is efficient and its synergies are optimally exploited. Further, they have stated that India should not miss another opportunity to demonstrate the world's largest democracy. It cares for its people, especially the deprived and the vulnerable and that it is truly marching ahead in its quest to become a welfare state.

Sharma and Didwania (2013) have noticed an improvement in the awareness of the beneficiaries and observed the positive effects of the programme, especially on beneficiaries. It can be identified in terms of its physical performance with respect to providing demand-based work and creating social community assets through full utilization of central and state government's financial and non-financial support. It indicates the positive sign of growth and development of rural areas as well as the nation.

Angamuthu (2017) has made an attempt to examine the physical performance of MGNREGS in India. The results of the analysis reveal that the number of employment demanded on an average has increased from the year 2012-13 to 2013-14 and gradually decreased thereafter. The study shows that the number of employment provided under the programme is falling continuously at a CAGR of 4.07 per cent on an average every year. The researcher has also found that the CAGR of women's participation remains higher than that of the SCs' and STs' participation for the respective given period. 
Michael (2018) carried out a study on "MGNREGA-An Appraisal of Performance with reference to Bangalore District" and observed that MGNEGA is focused on the formation of capital assets rather than employment. The researcher also found that from 2009 onwards Gram Panchayats are maintaining their official records in electronic format and doing various payments through electronic fund transfer. Meanwhile, the researcher analyzed that the pace of completion of work under the scheme is declining and job cardholders are reluctant to work under the scheme due to underpaying than the wage rate in the open market.

\section{RESEARCH GAP}

The Retrospective Literature is an integral part of the research process and makes a valuable contribution at almost every operational step. As far as literature on MGNREGS of Himachal Pradesh is concerned it is quite scanty and inadequate. However, the present study makes an attempt to fill the existing gap in the review of literature by conducting a study on the performance of MNREGS in Himachal Pradesh.

\section{DATA ANALYSIS AND INTERPRETATION}

1. Financial Performance of MGNREGS 2015-2020

\section{OBJECTIVES OF THE STUDY}

1. To examine the financial performance of MGNREGS with respect to fund utilization.

2. To evaluate the performance of MGNREGS in terms of employment demanded, employment provided, and employment completed.

\section{RESEARCH METHODOLOGY}

The present study is purely based on secondary data. For accomplishing the objectives of the study, data was collected from the website of Rural Development Department of Himachal Pradesh, India (https://rural.hp.gov.in/?q=annual-report accessed on 10/08/2021) for the period of 2015-2020 of last five years.

\section{TOOLS AND TECHNIQUES}

The statistical tools like Mean and CAGR are used for the analysis and interpretation of data.

Table No. 1

Funds Utilization under the MGNREGS: District-wise Analysis (Lakhs)

\begin{tabular}{|l|l|l|l|l|l|l|l|l|l|}
\hline Sr. No. & District & $\mathbf{2 0 1 5}$ & $\mathbf{2 0 1 6}$ & $\mathbf{2 0 1 7}$ & $\mathbf{2 0 1 8}$ & $\mathbf{2 0 1 9}$ & $\mathbf{2 0 2 0}$ & Mean & CAGR \\
\hline 1 & Bilaspur & 2119.84 & 1792.26 & 2816.41 & 2820.61 & 3418.67 & 2340.68 & 2551.41 & $2.00 \%$ \\
\hline 2 & Chamba & 6543.27 & 6009.08 & 9005.63 & 8607.37 & 12942.9 & 14274.1 & 9563.72 & $16.88 \%$ \\
\hline 3 & Hamirpur & 1748.37 & 1718.08 & 2379.88 & 2319.31 & 3240.99 & 3145.05 & 2425.28 & $12.46 \%$ \\
\hline 4 & Kangra & 7070.2 & 7441.53 & 9743.98 & 10589.7 & 16151.7 & 11610.2 & 10434.56 & $10.43 \%$ \\
\hline 5 & Kinnaur & 686.34 & 1113.67 & 1041.43 & 1193.48 & 2171.42 & 2170.17 & 1396.09 & $25.89 \%$ \\
\hline 6 & Kullu & 2772.88 & 2444.75 & 4316.14 & 4414 & 5743.47 & 4654.69 & 4057.66 & $10.92 \%$ \\
\hline 7 & Lahaul-Spiti & 251.14 & 270.68 & 351.67 & 359.86 & 292.64 & 328.25 & 309.04 & $5.50 \%$ \\
\hline 8 & Mandi & 10381.95 & 10157.39 & 13938.4 & 12435.9 & 18442.3 & 16571.4 & 13654.56 & $9.80 \%$ \\
\hline 9 & Shimla & 3342.42 & 3192.98 & 4609.25 & 5049.86 & 6029.25 & 5039.77 & 4543.92 & $8.56 \%$ \\
\hline 10. & Sirmaur & 3026.74 & 2328.99 & 3989.67 & 4305.5 & 7152.99 & 4654.56 & 4243.08 & $8.99 \%$ \\
\hline 11. & Solan & 1242.12 & 1225.04 & 1816.94 & 2042.2 & 2911.01 & 2133.46 & 1895.13 & $11.43 \%$ \\
\hline 12. & Una & 1301.6 & 1456.1 & 2262.82 & 2605.42 & 4903.11 & 4024.65 & 2758.95 & $25.33 \%$ \\
\hline \multicolumn{2}{|l|}{ Total (HP) } & 40486.87 & 39150.55 & 56272.2 & 56743.2 & 83400.5 & 70947 & 57833.38 & $11.87 \%$ \\
\hline
\end{tabular}

Source: HP RDD Annual reports 2015, 2016, 2017, 2018, 2019 and 2020.

The table reveals the district-wise analysis of funds utilized under the MGNREGS during the period from 2015 to 2020. It is found from the table that on average the highest mean value of fund utilization is 13654.56 in lakhs from the year 2015 to 2020 in Mandi district and the lowest average mean value of fund utilization is 309.04 in lakhs for the last six years (20152020) in Lahaul-Spiti district. The overall average mean value of fund utilization from 2015 to 2020 is 57833.38 in lakhs. Likewise, CAGR, as seen from the table that the highest per cent i.e. 25.89 per cent on average increases the fund utilization in Kinnaur district and it is followed by Una by 25.33 per cent each and the lowest 2 per cent of average declining of Bilaspur district during the same period of time. Thus it can be summarized that overall fund utilization is increased by an average of 11.87 per cent for the given period of time in Himachal Pradesh.

\section{Employment Demanded under MGNREGS 2015-2020}

Table No. 2

District-wise Allocation: Employment Demanded by Households

\begin{tabular}{|l|l|l|l|l|l|l|l|l|l|}
\hline Sr. No. & District & $\mathbf{2 0 1 5}$ & $\mathbf{2 0 1 6}$ & $\mathbf{2 0 1 7}$ & $\mathbf{2 0 1 8}$ & $\mathbf{2 0 1 9}$ & $\mathbf{2 0 2 0}$ & Mean & CAGR \\
\hline 1 & Bilaspur & 24216 & 21973 & 29056 & 28048 & 26925 & 23882 & 25683.33 & $-0.28 \%$ \\
\hline 2 & Chamba & 66543 & 61085 & 76728 & 72957 & 81775 & 91667 & 75125.83 & $6.62 \%$ \\
\hline
\end{tabular}




\begin{tabular}{|l|l|l|l|l|l|l|l|l|l|}
\hline 3 & Hamirpur & 23217 & 20718 & 26853 & 26134 & 28729 & 29966 & 25936.17 & $5.24 \%$ \\
\hline 4 & Kangra & 90243 & 86440 & 103626 & 104322 & 109257 & 99869 & 98959.50 & $2.05 \%$ \\
\hline 5 & Kinnaur & 9474 & 9259 & 10058 & 9702 & 11683 & 11774 & 10325.00 & $4.44 \%$ \\
\hline 6 & Kullu & 43251 & 38684 & 47659 & 48004 & 48397 & 46038 & 45338.83 & $1.26 \%$ \\
\hline 7 & Lahaul-Spiti & 3739 & 3937 & 3463 & 2953 & 3270 & 3498 & 3476.67 & $-1.32 \%$ \\
\hline 8 & Mandi & 126532 & 125458 & 143356 & 133330 & 144657 & 142555 & 135981.33 & $2.41 \%$ \\
\hline 9 & Shimla & 47203 & 43391 & 51105 & 50919 & 51467 & 53940 & 49670.83 & $2.70 \%$ \\
\hline 10. & Sirmaur & 33980 & 24712 & 36379 & 34027 & 40194 & 34242 & 33922.33 & $0.15 \%$ \\
\hline 11. & Solan & 16860 & 15354 & 19955 & 19916 & 22060 & 19469 & 18935.67 & $2.92 \%$ \\
\hline 12. & Una & 14160 & 15761 & 21382 & 20452 & 23956 & 23674 & 19897.50 & $10.83 \%$ \\
\hline \multicolumn{2}{|l|}{ Total (HP) } & 499418 & 466772 & 569620 & 550764 & 592370 & 580574 & 543253.00 & $3.06 \%$ \\
\hline
\end{tabular}

Source: HP RDD Annual reports 2015, 2016, 2017, 2018, 2019 and 2020.

The table exhibits district-wise bifurcation of employment demanded by households from 2015 to 2020 . It is quite clear from the above table that the highest average mean score of 135981.33 has been attained by Mandi district and the lowest 3476.67 has been attained by Lahaul-Spiti district for employment demanded during the above mentioned period. The overall mean score of employment demanded in Himachal Pradesh is 543253.00 for the same period of time. After evaluation of the CAGR, it is clear that the Una district has been growing by the highest per cent i.e. 10.83 per cent for the period of 2015 to 2020 and the lowest Sirmaur district by 0.15 per cent for the above said period. So it can be concluded that overall employment demand has increased positively in Himachal Pradesh by 3.06 per cent for the period of 2015 to 2020 .

\section{Employment Provided under MGNREGS 2015-2020}

Table No. 3

District-wise Distribution: Employment Provided to Rural Households

\begin{tabular}{|l|l|l|l|l|l|l|l|l|l|}
\hline Sr. No. & District & $\mathbf{2 0 1 5}$ & $\mathbf{2 0 1 6}$ & $\mathbf{2 0 1 7}$ & $\mathbf{2 0 1 8}$ & $\mathbf{2 0 1 9}$ & $\mathbf{2 0 2 0}$ & Mean & CAGR \\
\hline 1 & Bilaspur & 21495 & 19703 & 26586 & 25013 & 24585 & 20449 & 22971.83 & $-0.99 \%$ \\
\hline 2 & Chamba & 60250 & 54808 & 71580 & 68367 & 76835 & 86479 & 69719.83 & $7.50 \%$ \\
\hline 3 & Hamirpur & 21029 & 18714 & 24508 & 23853 & 26543 & 26991 & 23606.33 & $5.12 \%$ \\
\hline 4 & Kangra & 78345 & 75968 & 93133 & 95255 & 99662 & 89075 & 88573.00 & $2.60 \%$ \\
\hline 5 & Kinnaur & 8982 & 8719 & 9605 & 9179 & 11329 & 11367 & 9863.50 & $4.82 \%$ \\
\hline 6 & Kullu & 40842 & 36214 & 45250 & 45878 & 45906 & 43367 & 42909.50 & $1.21 \%$ \\
\hline 7 & Lahaul-Spiti & 3502 & 3355 & 3336 & 2779 & 3068 & 3293 & 3222.17 & $-1.22 \%$ \\
\hline 8 & Mandi & 117051 & 116300 & 136568 & 125792 & 137200 & 133300 & 127701.83 & $2.63 \%$ \\
\hline 9 & Shimla & 44122 & 40553 & 48082 & 47419 & 48604 & 50111 & 46481.83 & $2.58 \%$ \\
\hline 10. & Sirmaur & 30634 & 21767 & 33144 & 31076 & 37379 & 30833 & 30805.50 & $0.13 \%$ \\
\hline 11. & Solan & 13946 & 12867 & 17782 & 17919 & 20213 & 16814 & 16590.17 & $3.81 \%$ \\
\hline 12. & Una & 12190 & 13911 & 19255 & 18837 & 22317 & 21840 & 18058.33 & $12.37 \%$ \\
\hline \multicolumn{2}{|l|}{ Total (HP) } & 452388 & 422879 & 528829 & 511367 & 553641 & 533919 & 500503.83 & $3.37 \%$ \\
\hline
\end{tabular}

Source: HP RDD Annual reports 2015, 2016, 2017, 2018, 2019 and 2020.

The table depicts the figure related to employment offered by the district rural development agency for rural households. It is quite clear from the table that CAGR for Chamba, Hamirpur, Kangra, Kinnaur, Kullu, Mandi, Shimla, Solan and Una districts has continuously grown for the period of 2015 to 2020 by 7.50 , $5.12,2.60,4.82,1.21,2.63,2.58,3.81$ and 12.37 per cent respectively. On the other side, Bilaspur and Lahaul-Spiti districts' growth have been declined for the same period. Thus, it can be summarized that the overall growth of employment provided by a district development agency to rural households has grown by 3.37 per cent for the aforesaid period.

\section{Employment Completed under MGNREGS 2015-2020}


Table No. 4

Employment Completed under MGNREGS: District-wise Bifurcation

\begin{tabular}{|l|l|l|l|l|l|l|l|l|l|}
\hline Sr. No. & District & $\mathbf{2 0 1 5}$ & $\mathbf{2 0 1 6}$ & $\mathbf{2 0 1 7}$ & $\mathbf{2 0 1 8}$ & $\mathbf{2 0 1 9}$ & $\mathbf{2 0 2 0}$ & Mean & CAGR \\
\hline 1 & Bilaspur & 1472 & 956 & 683 & 606 & 2346 & 1594 & 1276.17 & $1.61 \%$ \\
\hline 2 & Chamba & 4174 & 3828 & 1500 & 3026 & 17237 & 24930 & 9115.83 & $42.97 \%$ \\
\hline 3 & Hamirpur & 853 & 682 & 359 & 429 & 1826 & 1700 & 974.83 & $14.79 \%$ \\
\hline 4 & Kangra & 2244 & 3020 & 707 & 1207 & 9908 & 5281 & 3727.83 & $18.67 \%$ \\
\hline 5 & Kinnaur & 343 & 502 & 374 & 162 & 2003 & 1818 & 867.00 & $39.59 \%$ \\
\hline 6 & Kullu & 1027 & 627 & 960 & 1402 & 3601 & 3131 & 1791.33 & $24.97 \%$ \\
\hline 7 & Lahaul-Spiti & 196 & 74 & 113 & 42 & 74 & 95 & 99.00 & $-13.48 \%$ \\
\hline 8 & Mandi & 6427 & 6785 & 3413 & 3838 & 16648 & 10696 & 7967.83 & $10.72 \%$ \\
\hline 9 & Shimla & 821 & 835 & 547 & 745 & 3085 & 3363 & 1566.00 & $32.58 \%$ \\
\hline 10. & Sirmaur & 2451 & 1169 & 1107 & 1512 & 7109 & 3854 & 2867.00 & $9.47 \%$ \\
\hline 11. & Solan & 682 & 559 & 354 & 486 & 2203 & 1256 & 923.33 & $12.99 \%$ \\
\hline 12. & Una & 843 & 1215 & 1009 & 639 & 4281 & 2888 & 1812.50 & $27.92 \%$ \\
\hline \multicolumn{2}{|l|}{ Total (HP) } & 21533 & 20252 & 11126 & 14094 & 70321 & 60606 & 32988.67 & $22.99 \%$ \\
\hline
\end{tabular}

Source: HP RDD Annual reports 2015, 2016, 2017, 2018, 2019 and 2020.

The above table shows the figures related to the offered employment completed by rural households under the MGNREGS during the years 2015 to 2020 . It is quite clear from the table that all districts have continuously increasing trends of growth during the period from 2015 to 2020 except the Lahaul-Spiti district. It has a negative growth rate i.e. 13.48 per cent for the same period. The overall state-level growth of employment completion by a household has increased by 22.99 per cent for the period from 2015 to 2020. So, it can be inferred that offered employment completion has grown up by 28 per cent for the above-mentioned period.

\section{THE MAJOR FINDINGS OF THE STUDY}

- The Double-digit positive value of fund utilization approves the significant performance of MGNREGS in Himachal Pradesh.

- Employment Demand is grown in all districts except two districts i.e. Bilaspur and Lahaul-Spiti. The overall growth has been seen 3.67 per cent for 2015-20.

- Rural Development Department offered employment on demand average 5 Lakhs people per year for the period of 2015-20 and it (employment offer) is grown by 3 per cent approx. for the said period.

- Approximate 33000 households per year accomplishing hundred days of assured work under the programme during 2015-20. The overall growth has been found 22.99 per cent from 2015 to 2020.

\section{CONCLUSION}

The above findings lead to the conclusion that MGNREGS is playing a significant role in hammering on rural poverty by making available guaranteed hundred days of employment in a financial year to every household. Since its inception, the growth has been noticed in every phase of the programme, whether it is in the progress of the expenditure of the allocated budget or the demand for employment by the rural people. Apart from this, representatives of Panchayati Raj Institutions and rural households are also playing their positive role in this, by offering employment and completing that employment with full determination.

\section{REFERENCES}

[1] Rengasamy, Kalarani. \& Kumar, B. Sasi. (2011). State-Level Performance of MGNREGA in India: A Comparative Study. International Multidisciplinary Research Journal, 1(10), 36-40.

[2] Sharma, Rajesh. \& Didwania, Manish. (2013). Performance Analysis of MGNREGA: A Case Study of District Jind. ZENITH International Journal of Business Economics \& Management Research, 3(8), 155-165.

[3] Angamuthu, R.A. (2017). Study on Physical Performance of MGNREGS in India. SSRG International Journal of Economics and Management Studies, 4(5), 21-24.

[4] Michael, Selvakumar Joseph. (2018). MGNREGA-An Appraisal of Performance with reference to Bangalore District. International Journal of Creative Research Thoughts (IJCRT), 6(2), 849-853.

[5] www.mgnrega.nic.in/Nregahome/MGNREGA_new/Nrega_home.aspx

[6] https://rural.hp.gov.in/

[7] https://hppanchayat.nic.in/

[8] https://www.census2011.co.in

\section{AUTHORS}

First Author - Dr. Tek Chand, Assistant Professor, Dept. of Commerce, SLC Eve., University of Delhi. 
